

\title{
Clinoform Generation on Mediterranean Margins
}

BY ANTONIO CATTANEO, FABIO TRINCARDI,

\author{
LEONARDO LANGONE, ALESSANDRA ASIOLI, AND PERE PUIG
}

\begin{abstract}
"Clinoform" is a term originally introduced by Rich (1951) to describe the shape of a depositional surface at the scale of the entire continental margin (Figure 1a). In the current geologic literature, the term "clinoform" denotes strata packages with oblique internal layering, best imaged on seismic reflection profiles, where three geometric elements are recognized: (1) "topset," the most shallow and low-angle area, (2) "foreset," the central and steepest area, and (3) "bottomset," the flat area farther basinward (Figure 1b) (Mitchum et al., 1977). The break in seafloor slope between the topset and the foreset is often called the "rollover point."

Since the advent of seismic stratigraphy, clinoforms have been observed over several spatial and temporal scales in highly diverse geologic settings (Figure 1c). Typically, clinoforms are defined on vertical scales ranging from several meters to several hundreds of meters and encompass intervals ranging from hundreds to millions of years. In the study of modern continental margins, clinoforms are widely recognized as one of the fundamental building blocks of the stratigraphic record.

Over millions of years, the entire continental margin can be viewed as a clinoform, including the continental shelf as a transfer area, the continental slope as the main area of sediment accumulation, and the base of the slope as a distal bottomset. Changes in clinoform thickness, internal geometry, and style of superposition of multiple clinoforms provide information on long-term margin subsidence, sea-level change, and short-term fluctuations of sediment supply. Clinoforms forming over a few thousands of years are observed on the inner shelf of diverse margins: tectonically passive settings, such as the Amazon prodelta (Nittrouer et al., 1986); active-margin settings,
\end{abstract}




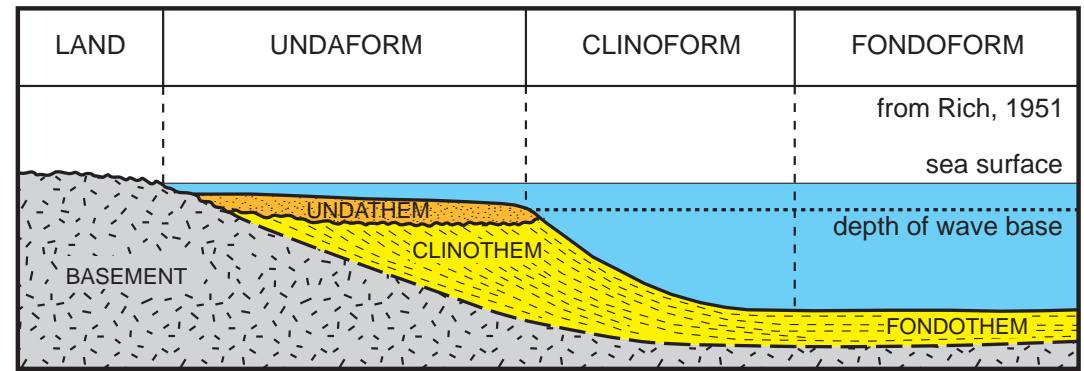

$\mathrm{b}$

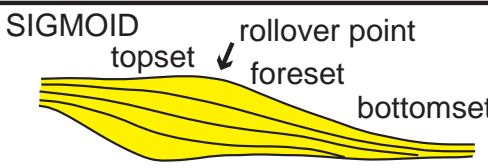

OBLIQUE

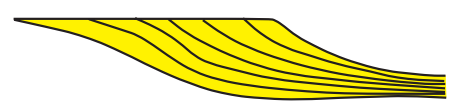

TANGENTIAL

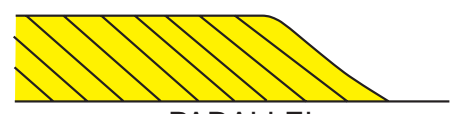

PARALLEL

modified from Mitchum et al., 1977

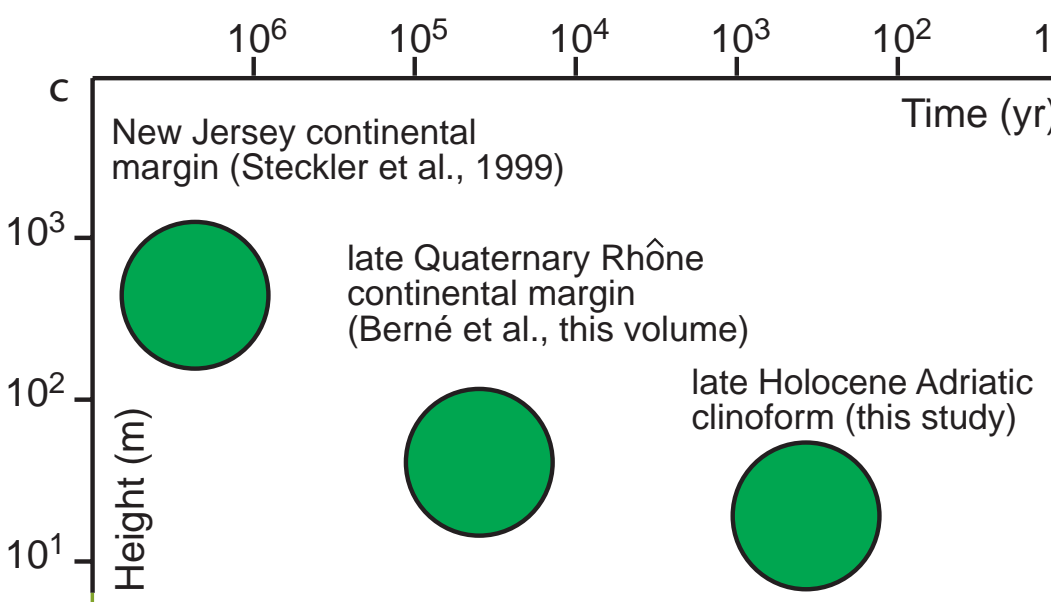

Figure 1. (a) Diagram showing the original definition of clinoform from Rich (1951). (b) Main clinoform types commonly observed on seismic-reflection profiles on continental margins (from Mitchum et al., 1977). Within the clinoform, "topset" indicates the landward and shallowest area with low-angle surfaces, "foreset" is the area with the steepest surfaces, and "bottomset" is the area with low angle surfaces in a basinward position. (c) Diagram showing time scales (years on the horizontal axis) and dimension of clinoforms (expressed by their height in meters). The New Jersey continental margin shows kilometer-thick clinoforms formed over tens of millions of years; late Quaternary clinoforms composing parts of continental margins reflect glacial-interglacial cyclicity at the scale of hundreds of thousands of years with thickness of several tens to hundreds of meters; late Holocene clinoforms on modern continental shelves (this study) formed during the last few thousand years and are up to a few tens of meters thick. such as the Ganges-Brahmaputra (Goodbred et al., 2003); and broad epicontinental shelves (Alexander et al., 1991).

In the study of continental margins, sedimentary geology is concerned with the reconstruction of the internal geometry of sedimentary bodies to infer their relation with sedimentary processes.

These processes can either be inferred based on sedimentary structures preserved in the geologic record or be directly measured over scales of hours to decades. However, any inference about possible sedimentary processes depends significantly on our understanding of those processes that can be observed today. On the other hand, sedimentary processes that can be observed today do not necessarily include the full range of possible mechanisms that leave a major signal in the stratigraphic record. Trying to establish a genetic relationship between observation of oceanographic processes and continental-margin stratigraphy is a major goal of a vast community

Antonio Cattaneo (antonio.cattaneo@bo. ismar.cnr.it) is Research Scientist, Istituto di Scienze Marine-Consiglio Nazionale delle Ricerche (ISMAR-CNR), Bologna, Italy. Fabio Trincardi is Senior Research Scientist, Istituto di Scienze Marine-Consiglio Nazionale delle Ricerche (ISMAR-CNR), Bologna, Italy. Leonardo Langone is Research Scientist, Istituto di Scienze Marine-Consiglio Nazionale delle Ricerche (ISMAR-CNR), Bologna, Italy.

Alessandra Asioli is Research Scientist, Istituto di Geoscienze e Georisorse-Consiglio Nazionale delle Ricerche (IGG-CNR), Padova, Italy. Pere Puig is Research Scientist, Institut de Ciències del Mar-Consejo Superior de Investigaciones Científicas (CMIMA(SIC), Barcelona, Spain. 
of researchers worldwide. The choice of EURODELTA and EUROSTRATAFORM projects to study the growth of Mediterranean late-Holocene clinoforms derives from the possibility of linking direct measurement of sediment-transport processes to the stratigraphy over intervals of thousands of years.
THE MEDITERRANEAN LATE HOLOCENE SHELF CLINOFORMS

Seaward of major deltas, the Mediterranean margins exhibit extensive muddy shelf clinoforms, up to several tens of meters thick (Figure 2). These clinoforms typically have sediment accumulation rates exceeding $1.5 \mathrm{~cm} / \mathrm{yr}$ and have been building since the mid Holocene, when sea level reached approximately its present position (Stanley and Warne, 1994). Because the combined effect of oceanographic processes redistributes river-borne sediment predominantly along the shelf, Mediterranean late Holocene clinoforms extend hundreds of
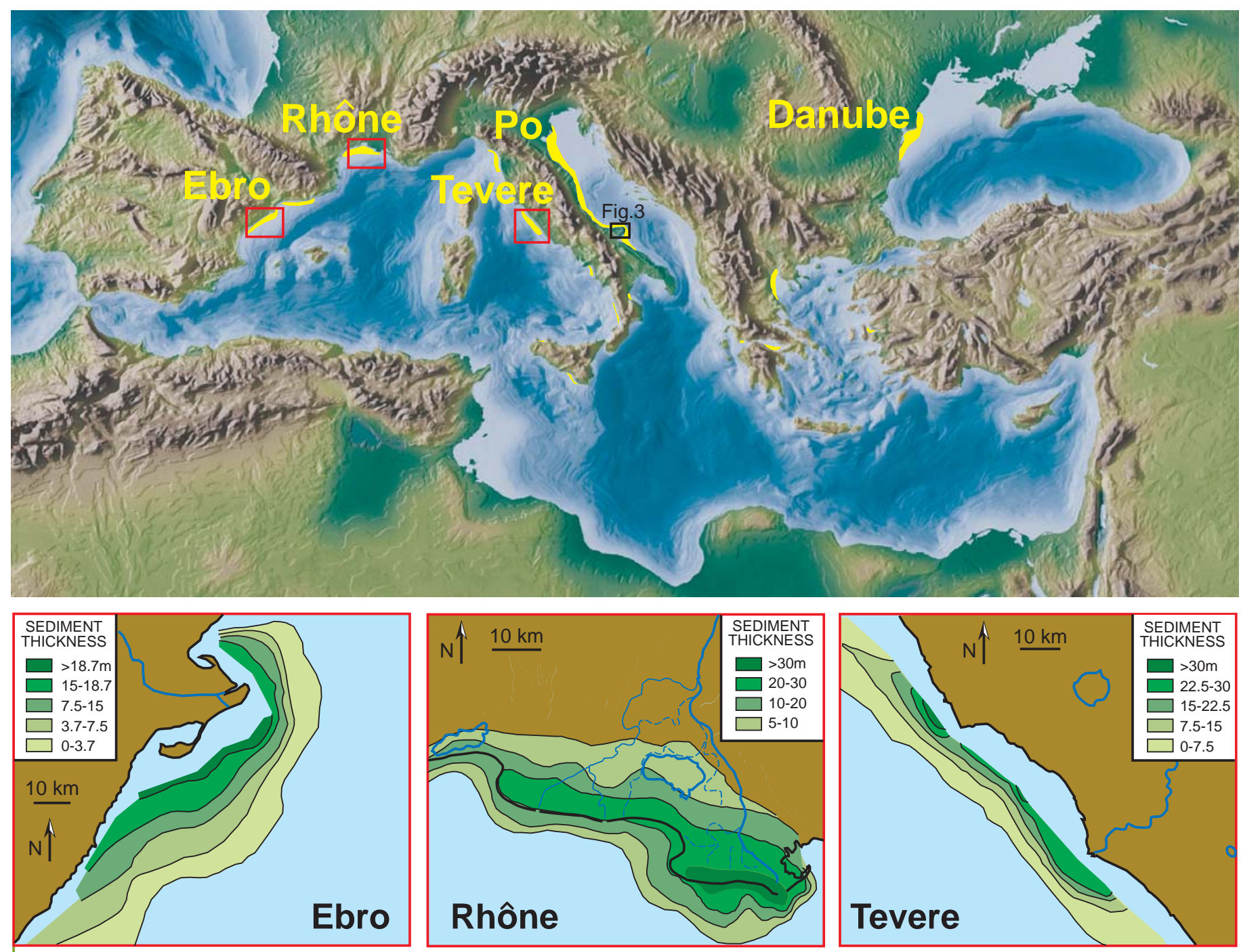

Figure 2. The main north Mediterranean and Black Sea shelf clinoforms grow under the influence of deltaic systems and represent a crucial link in our understanding of the short- and long-term interactions between fluviodeltaic and marine sedimentation processes. Inset: thickness maps of clinoforms offshore the Ebro (modified from Diaz et al., 1990), Rhône (modified from Gensous and Tesson, 2003), and Tevere deltas. These maps, based on the analysis of seismic-re-

flection profiles and sediment cores, document the asymmetric distribution of clinoform deposits with respect to their sediment sources. 
kilometers away from major deltas and exhibit thickness distributions that appear strongly asymmetric with respect to their parent deltas. Both of these characteristics reflect the role of regional circulation patterns.

Mediterranean late Holocene clinoforms share several characteristics: (1) they have fine-grained deposits as great as $35 \mathrm{~m}$ thick, (2) they have very lowangle features with a foreset steepness of 1 degree or less, (3) they are best developed on the downdrift side of their parent delta relative to the dominant shelfcurrent regime, and (4) they have a bottomset region characterized by a sharp termination of seismic reflectors or, more commonly, by a low-angle transition to a draped shelf deposit. The study of modern Mediterranean clinoforms allows us to reconstruct in detail the clinoforms' internal geometry and to compare it with direct observations of dominant sediment-transport processes. Furthermore, study of this geologically short interval makes it possible to disregard the effects of sea-level fluctuations and tectonics, which represent major controlling factors on margin stratigraphy over longer time scales (Berné et al., this issue). For example, simplified dynamic models explain the origin of clinoforms based on gradual variations of the shear stress on the seafloor, induced by waves or bottom currents, as the primary controlling parameter (Pirmez et al., 1998).

Innovative methods of studying modern clinoforms include geophysical subsurface and seafloor imaging, geochronology, micropaleontology, process studies, and conceptual and numerical models. A summary of the results of multidisciplinary research on the late Holocene clinoform of the Adriatic shelf is presented here. This research was performed by EURODELTA and EUROSTRATAFORM projects and funded by the European Union and the U.S. Office of Naval Research. The main goal of this article is to define how understanding modern sediment-transport processes can be used to explain the growth of a clinoform over geological scales of thousands of years.

\section{ANATOMY OF THE ADRIATIC SHELF CLINOFORM}

The modern Adriatic Sea is a narrow epicontinental basin (ca. 200 x $800 \mathrm{~km}$ ) (Figure 2) with a low topographic gradient (ca. 0.02 degrees) in the north, and a steeper shelf farther south. The basin has a microtidal regime and is dominated by a cyclonic circulation driven by thermohaline currents (Poulain, 2001). On the Adriatic shelf, as on several other Mediterranean shelves, the late Holocene clinoform reaches up to $35 \mathrm{~m}$ in thickness with a volume of almost two hundred cubic kilometers (Cattaneo et al., 2003).

On seismic profiles perpendicular to the coast, the Adriatic shelf clinoform shows relatively steeply dipping foresets (typically 0.5 to 1 degree) and is composed of elementary sigmoidal units (Figure 3). A prominent morphologic feature is the subaqueous "rollover point" (separating topset and foreset strata) in about $25 \mathrm{~m}$ water depth. This diagnostic feature can be traced approximately $350 \mathrm{~km}$ along the coast north of the Gargano promontory (Figure 3). As suggested by direct dating on the basal surface, and interpolations of sediment accumulation rates derived from short- lived radionuclides $\left({ }^{210} \mathrm{~Pb}\right)$, the most recent portion of the clinoform was likely deposited during the last 500 years (Frignani et al., in press; Nittrouer et al., this issue), an interval encompassing the Little Ice Age. Offshore the Gargano promontory, where the interaction between shore-parallel southward flowing currents and basin morphology is at its maximum, the clinoform advances onto a flat bedrock outcrop in about 50-80 m water depth. The rapid cross-shelf transition from a thickness of $30 \mathrm{~m}$ of mud to $0 \mathrm{~m}$ is a good indication of the role played by southward-flowing, bottomhugging currents that prevent deposition in the bottomset and cause sediment redistribution along the shelf (Figure 3 ).

\section{MULTIPROXY ANALYSIS ON A SEDIMENT CORE: RF93-30}

While the geometry of clinoforms is well imaged on seismic reflection profiles, any quantification of changes in sediment accumulation rates through time requires a multidisciplinary study of long sediment cores. In particular, a firm geochronological framework needs to be established by integrating complementary dating techniques, including radiometric dating $\left({ }^{14} \mathrm{C},{ }^{210} \mathrm{~Pb}\right)$, secular variations of the magnetic field (inclination, declination), and tephrochronology (as discussed in Oldfield et al., 2003). This geochronological analysis allows us to identify variations in sediment accumulation rates (and therefore changes in sediment supply from the continent) that can be attributed to global or regional environmental change through the analysis of paleo-environmental indicators. These indicators include benthonic foraminifera assemblages (repre- 


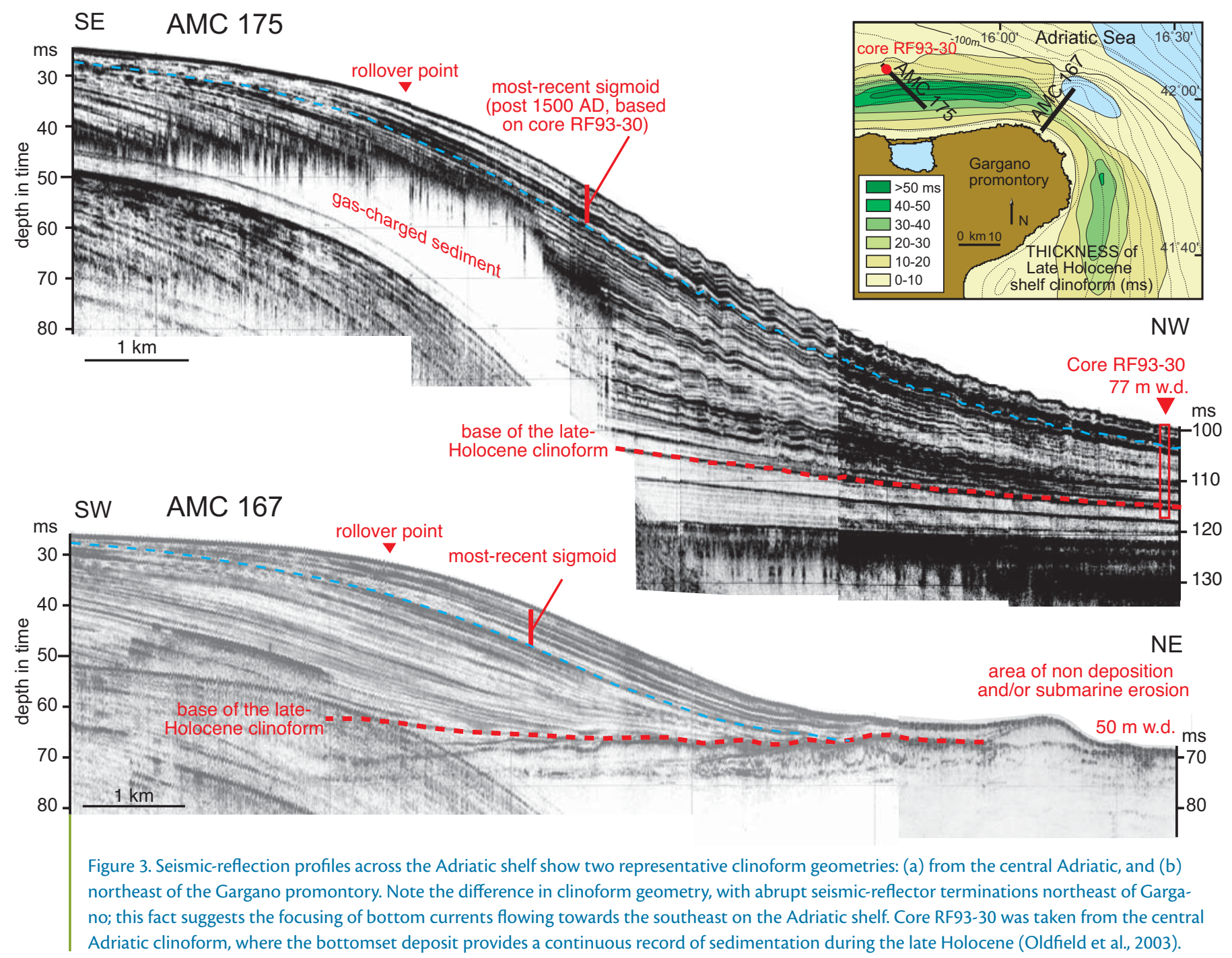

sentative of seafloor conditions), pollen spectra (recording changes in land cover on the nearby continent), and geochemical tracers such as stable isotopes and alkenones (providing information on changing water-mass stratification and temperature). This kind of integrated information can be extracted from only a few key cores; however, it can be extrapolated regionally through seismic stratigraphic correlation accompanied by matching key parameters from several coring sites (Figure 4).

Core RF93-30 is from an area of bottomset deposition $350 \mathrm{~km}$ south of the Po delta. The core provides an integrated record of environmental changes over the entire Adriatic basin. The chronology of sedimentation in core RF93-30 is based on AMS (accelerator mass spec- trometer) ${ }^{14} \mathrm{C}$ dates of foraminifera extracted from the core, palaeomagnetic secular variation, pollen abundance and dated "tephra" (tephra is a layer of glass shards and minerals ejected from a volcanic eruption and transported by wind). Changes in pollen abundances show at least two intervals of deforestation recorded by abrupt decreases in the relative abundance of broad-leaved 


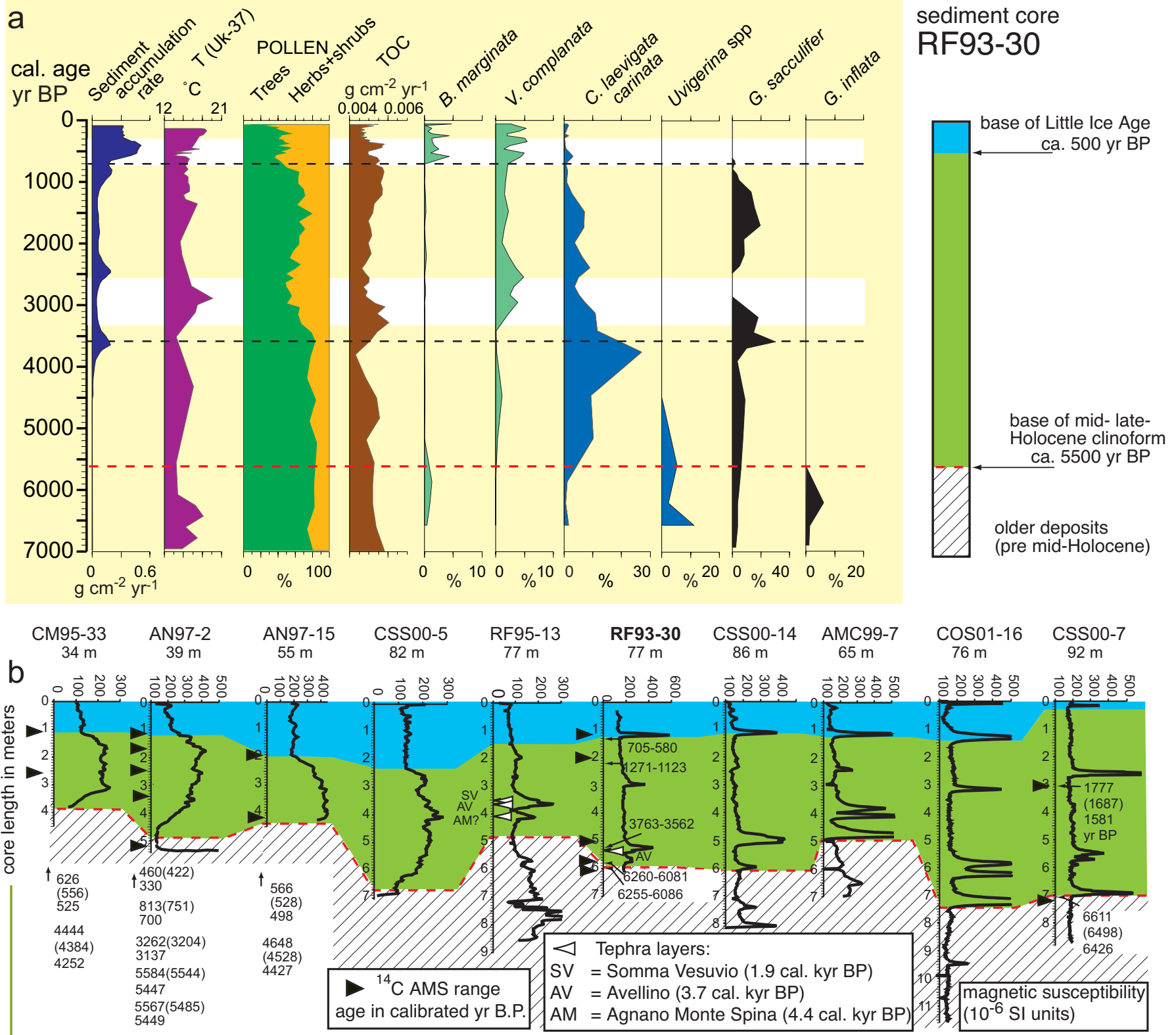

Figure 4 (a) Core RF93-30 reveals a sequence of changes in terrestrial vegetation, terrigenous sediment input, and benthic fauna, as well as evidence for variations in sea surface temperature spanning the last 7000 years. Around 3600 years before present (Late Bronze Age) and 700 years before present (Medieval), two dashed black lines mark the onset of accelerations in sedimentation, reflecting the response of surface processes (e.g., soil erosion) to widespread forest clearance and cultivation (Oldfield et al., 2003). White bands highlight the consequent response of the environment seen in other biotic and abiotic parameters. Sea surface temperature (alkenone $U_{37}^{k}$ curve) is stable or increasing, indicating that the decrease of broadleaved trees, as seen in the pollen record, is caused by human impact and not by a climatic cooling. Benthic foraminifera data show the change from a less-sedimented shelf environment (before 5000 years before present) to a "mud belt" environment with much higher sediment-accumulation rates (Valvulineria complanata and Bulimina marginata), passing through a phase of decreased fluvial influence indicated by the dominance of Cassidulina laevigata carinata. The peaks of the planktonic species Globigerinoides sacculifer, a warm-water symbiont bearing species, suggest intervals of reduced turbidity of surface waters, confirming the decrease of the fluvial input. The disappearance of Globorotalia inflata approximates the onset of clinoform growth in the Adriatic Sea. (b) Correlation of Core RF93-30 to other cores through the Adriatic shelf clinoform based on reflection-seismic profiles, matching of magnetic susceptibility curves, ${ }^{14} \mathrm{C}$ dates and identified tephra layers (core location in Figures 3 and $5 \mathrm{~d}$ ). The section above the dashed red line represents the late Holocene shelf clinoform; in blue are the last 500 years encompassing the Little Ice Age (ca. 500-100 years before present) and the last century. 
trees since the late Bronze Age (ca. 3700 years before present) (Figure 4). These rapid episodes of deforestation result in increased soil erosion and, consequently, increased sediment flux to the clinoform. Increased concentrations of organic carbon (TOC) indicate higher productivity triggered by an augmented flux of nutrients from the continent. Interestingly, all of these environmental changes are paralleled by a significant increase of benthonic foraminifera species (Valvulineria complanata, Bulimina marginata) dwelling in rapidly accumulating mud; these changes indicate phases of enhanced growth of the Adriatic clinoform (Figure 4) (Box 1). During intervals of forest clearance, geochronological reconstructions indicate that sediment accumulation rates rose up to as much as 1.5 $\mathrm{cm} / \mathrm{yr}$. This kind of stratigraphic study documents how Mediterranean late Holocene clinoforms record short-term climatic changes and well-defined episodes of human impact through pulses in sediment supply.

Concern about human impact on global change is increasing. Not only is this impact evident since the advent of industrial revolution, but also it appears to have been crucial in raising the concentrations of greenhouse gases as early as eight thousand years before present (Ruddiman, 2003). To further understand past human impact, it is necessary to identify the best stratigraphic archives. In addition to the records provided by varved lakes or ice cores, Mediterranean clinoforms offer excellent chronological resolution and the possibility to link continental and oceanic signals of environmental change.
OBSERVATIONS OF CLINOFORM GROWTH ON COMPLEMENTARY

\section{TIME SCALES}

The growth patterns and internal architecture of the Adriatic late Holocene clinoform can be reconstructed over distinctive but complementary intervals (Figure 5). Such intervals extend from event, seasonal, or annual scales (Figure 5a) to stratigraphic intervals of increasing duration: (1) the last century (Figure $5 b),(2)$ the last 500 years (Figure 5c), and (3) the last 5000 years (Figure 5d). The choice of such subdivisions depends partly on the kind of tool used for stratigraphic observation and on the dating techniques employed; however, these subdivisions represent significant intervals such as the industrial revolution, the Little Ice Age, and the second half of the Holocene (Figures $5 \mathrm{~b}$ to $5 \mathrm{~d}$, respectively). Necessarily, each of these intervals extends to the present; therefore, information on longer time slices also includes progressively younger and shorter intervals. Comparing sediment distribution within these three complementary stratigraphic frames, and to oceanographic processes measured today, indicates that (on all time scales) sediment deposited away from this coastal belt is negligible or episodically removed by currents.

As a whole, the Adriatic clinoform encompasses the last ca. 5000 years, the entire interval of sea level high stand during the Holocene. Mapping and volume calculations for this unit derive from the interpretation of seismic reflection profiles and dating of sediment cores reaching its basal surface. At this scale, the distribution of the Adriatic clinoform shows three main elongated depocenters on the shelf: offshore the Po River delta, along the central Adriatic margin, and east of the Gargano promontory. The clinoform unit deposited during the last ca. 500 years can also be traced on seismic reflection profiles and by its basal horizons dated in sediment cores. The depocenter of this youngest unit is located seaward of the depocenter of the entire clinoform, indicating active outbuilding during the last 500 years. The clinoform during the last century was instead traced based on sediment accumulation derived from ${ }^{210} \mathrm{~Pb}$ shortlived radionuclides (Frignani et al., in press; Nittrouer et al., this issue). Sediment-accumulation rates were derived from a Constant Flux-Constant Sedimentation model (for more information, see Frignani et al., in press). The areas of maximum sediment accumulation rates during the last ca. 100 years are located farther seaward with respect to the position of the depocenters of the whole clinoform and to the clinoform unit representing the last 500 years. This offset is particularly evident in the areas east of the Gargano promontory. The presence of localized depocenters (compared to the more elongated sediment distribution averaged on longer intervals) reflects compensation in the sediment distribution along the margin (besides uneven spatial distribution of core data).

To establish relationships among active sediment dynamics, across-shelf transport, and sediment accumulation in the western Adriatic clinoform, two tripods and one mooring were deployed off the Pescara River (central Adriatic) during autumn and winter 2002/2003 as part of the EUROSTRATAFORM project, and in combination with the Po 


\section{BOX 1: FORAMINIFERA STUDIES IN CLINOFORM CHARACTERIZATION}

Foraminifera constitute the most diverse group of shelled microorganisms in the modern ocean. They live in the water column (planktonic foraminifera) or inhabit the ocean floor (benthic foraminifera). Foraminifera show a great variety and abundance both in the fossil record and in the modern marine environment, revealing high sensitivity to biotic and abiotic factors. Modern planktonic foraminifera show a latitudinal distribution (e.g., polar, subpolar, transitional, subtropical, and tropical provinces) as well as a vertical distribution in the water column (e.g., surface, intermediate, deep-water species); these distributions result from differences in water-mass temperatures, dissolved-oxygen concentrations, food availability, winter mixing, and trophic levels (Hemleben et al., 1989).

Benthic foraminifera are present in all marine environments from supratidal to abyssal sediments, and they live at the water-sediment interface (epifauna) or down to several centimeters within the sediment (shallow, intermediate, and deep infauna), where content of oxygen, food availability, and, today, toxic substances can be drastically different from the sediment-water interface (Jorissen, 1999). In this context, different "microhabitats" (microenvironments characterized by a combination of physical, chemical, and biological conditions) can be attractive for some organisms, but uninhabitable for others. The vertical distribution of a particular species may vary spatially or through time at a single site in response to environmental and oceanographic changes.

In the modern shelf environment, different assemblages are present: from the marsh association (useful as sea-level indicator and dominated by agglutinated and hyaline species) to the lagoon, inner shelf, and outer shelf-upper slope assemblages (see figure). In the outer shelf and upper slope, planktonic foraminifera are present, whereas, in the inner shelf, they are absent or rare. In a shelf environment affected by fluvial input, the interplay of fluvial discharge and transport by surface-water currents results in the deposition of fine-grained, organic-rich sediment roughly parallel to the coast, corresponding to the shelf clinoform (Van der Zwaan and Jorissen, 1991). Moreover, the fluvial input may lead to anoxic or dysoxic conditions even at great distances from a specific deltaic freshwater source. This environment affects the benthic foraminifera distribution, favoring the presence of opportunistic species. Van der Zwaan and Jorissen (1991) explained the seasonal changes in the microhabitat of benthic foraminifera based on two assumptions: (1) the oxygen level in the sediment controls the presence and type of benthos, and (2) several benthic organisms are exclusively epifaunal, while others are infaunal during periods of well oxygenated bottom waters (e.g., winter), and shift to an epifaunal position during periods of low oxygen concentrations in the sediments, (e.g., summer and autumn) (see figure). Changes of foraminifera associations recorded within older strata allow us to reconstruct changes in rate or style of clinoform growth. 
a marsh assemblage inner shelf: (sea-level indicator): hyaline (Ammonia and agglutinated and hyaline taxa

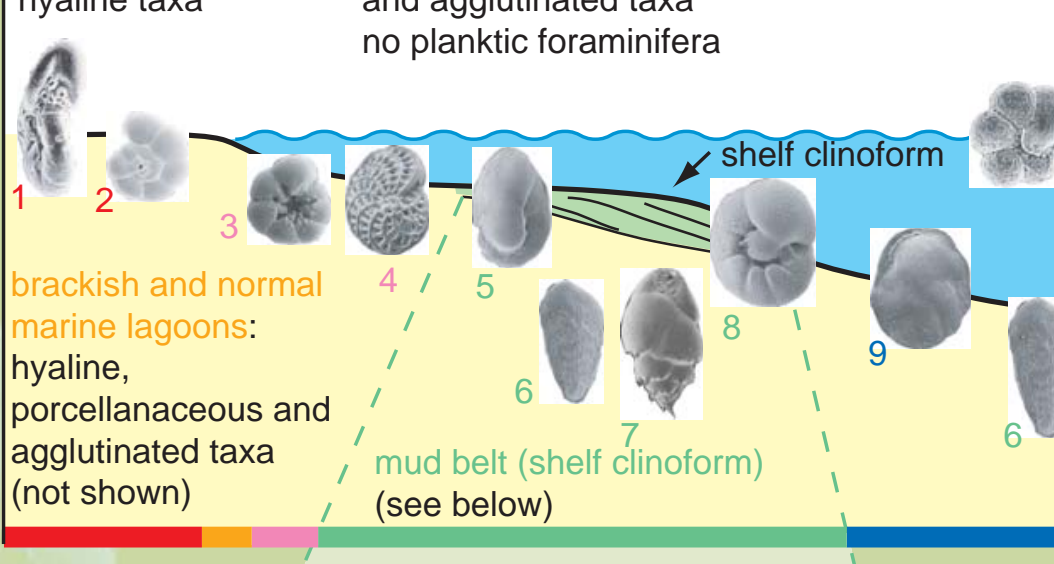

Elphidium), porcellanaceous and agglutinated taxa no planktic foraminifera outer shelf/upper slope assemblage:

hyaline (i.e. Uvigerina, Hyalinea,

Trifarina, Gyroidinoides, Bulimina,

Bolivina), porcellanaceous and agglutinated (Bigenerina, Textularia) taxa planktic forams present
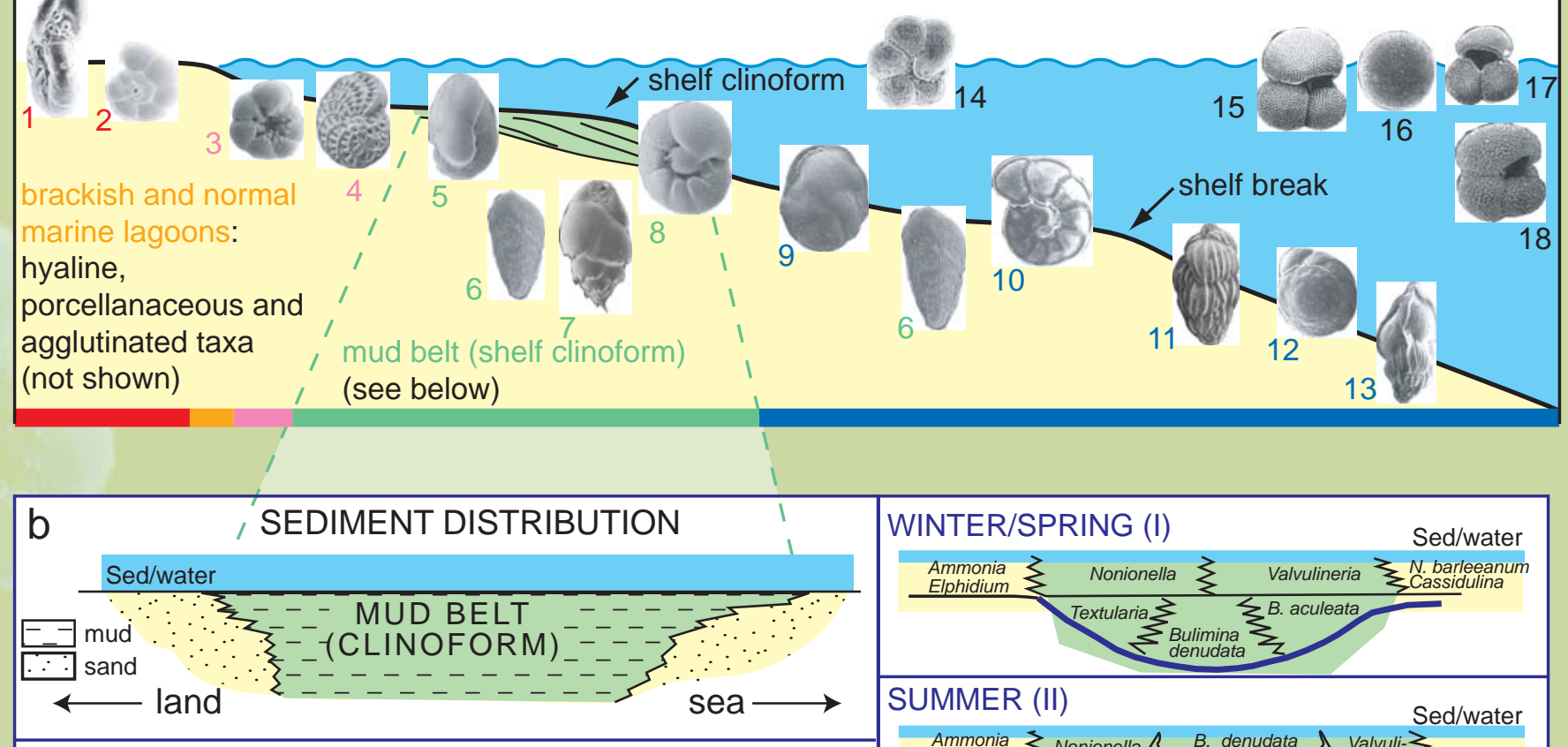

\section{CRITICAL OXYGEN LEVEL FOR INBENTHIC LIFE}
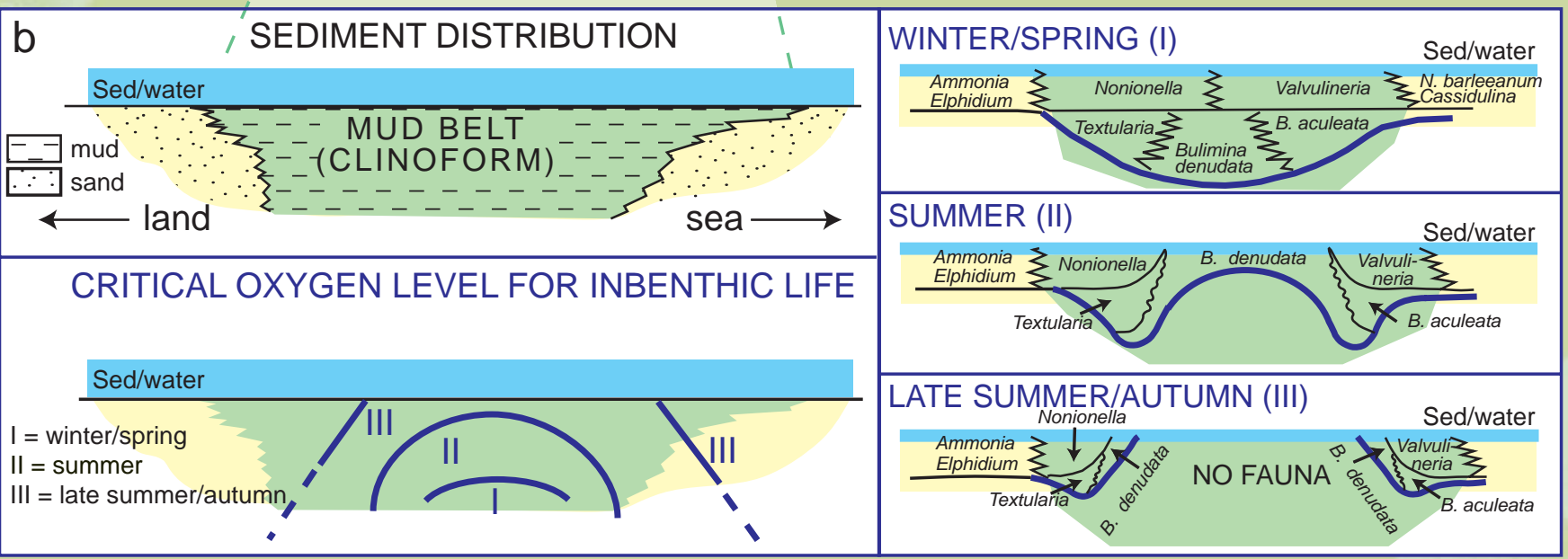

(a) Morphologic profile showing the different benthic and planctonic foraminifera assemblages in a continental shelf affected by fluvial discharge. (b) Model for microhabitat occupation during various stages of oxygen deficiency (from Van der Zwaan and Jorissen, 1991) based on a section across the Adriatic Sea shelf (from a nearshore sandy zone, stippled shading, passing to a muddy shelf clinoform). The Ammonia-Elphidium assemblage inhabits the nearshore zone, while Cassidulina laevigata and Melonis barleeanum dominate the most distal zone, less directly influenced by river outflow. In the shelf muddy clinoform during winter, the vertical succession includes epifauna (Nonionella turgida and Valvulineria complanata in somewhat deeper water) and infauna (Textularia and Bulimina marginata forma aculeata and forma denudata). When the critical oxygen level starts to rise in summer, infauna are forced to migrate to the epifaunal microhabitat; during the late summer/autumn, when oxygen concentration falls to minimum values, the center of the "mud belt" tends to be devoid of benthic life, resulting in a succession of microhabitats that is more compressed towards its outer edges (Van der Zwaan and Jorissen, 1991). Benthic foraminifera illustrated: 1. Trochammina macrescens, 2. Trochammina inflata, 3. Ammonia beccarii, 4. Elphidium gr. crispum, 5. Nonionella turgida, 6. Brizalina spathulata, 7. Bulimina gr. marginata, 8. Valvulineria complanata, 9. Cassidulina laevigata carinata, 10. Hyalinea balthica, 11. Uvigerina spp, 12. Cibicidoides pachyderma, 13. Trifarina angulosa. Planktonic foraminifera illustrated: 14. Globigerina quinqueloba, 15. Globigerinoides sacculifer, 16. Orbulina, 17. Globigerinoides ruber, 18. Globorotalia inflata. 
Figure 5. Maps of the Adriatic Sea show information on the shelf clinoform at complementary time scales ranging from ca. 10 to 5500 years before present. (a) MODIS satellite image (spring 2001) capturing the evolution of river plumes affected by current and coastal morphology (Courtesy of NASA's Visible Earth by K.Ward and the Earth Observatory team). White arrows indicate surface circulation (averaged measurements during the years 1990-1999 with Acoustic Doppler Current Profiler) (Poulain, 2001). (b) Contour map of ${ }^{210} \mathrm{~Pb}$-based mass-accumulation rates (last century) showing maximum accumulations offshore of the Po delta and along a narrow belt parallel to the coast (redrawn from Frignani et al., in press). (c) Thickness map from seismicreflection profiles of the upper sedimentary unit of the shelf clinoform deposited in the last $500 \mathrm{yr}$ and encompassing the Little Ice Age (dated ca. 500 to 100 years before present). TWTT = two way travel time; with a rough estimate of $1500 \mathrm{~m} \mathrm{~s}^{-1}$ for sound speed in water and superficial sediment, 10 milliseconds correspond to $7.5 \mathrm{~m}$. (d) Thickness map from seismic-reflection profiles of the whole shelf clinoform deposited during the last 5500 years with location of key sediment cores (black dots). As a whole, the shelf clinoform has three distinct areas of maximum sediment accumulation: offshore the Po delta, along the central Adriatic margin, and eastwards of the Gargano promontory. All scales of observation show consistently that sediment is efficiently redistributed in a shore-parallel direction following the counterclockwise circulation of the Adriatic.
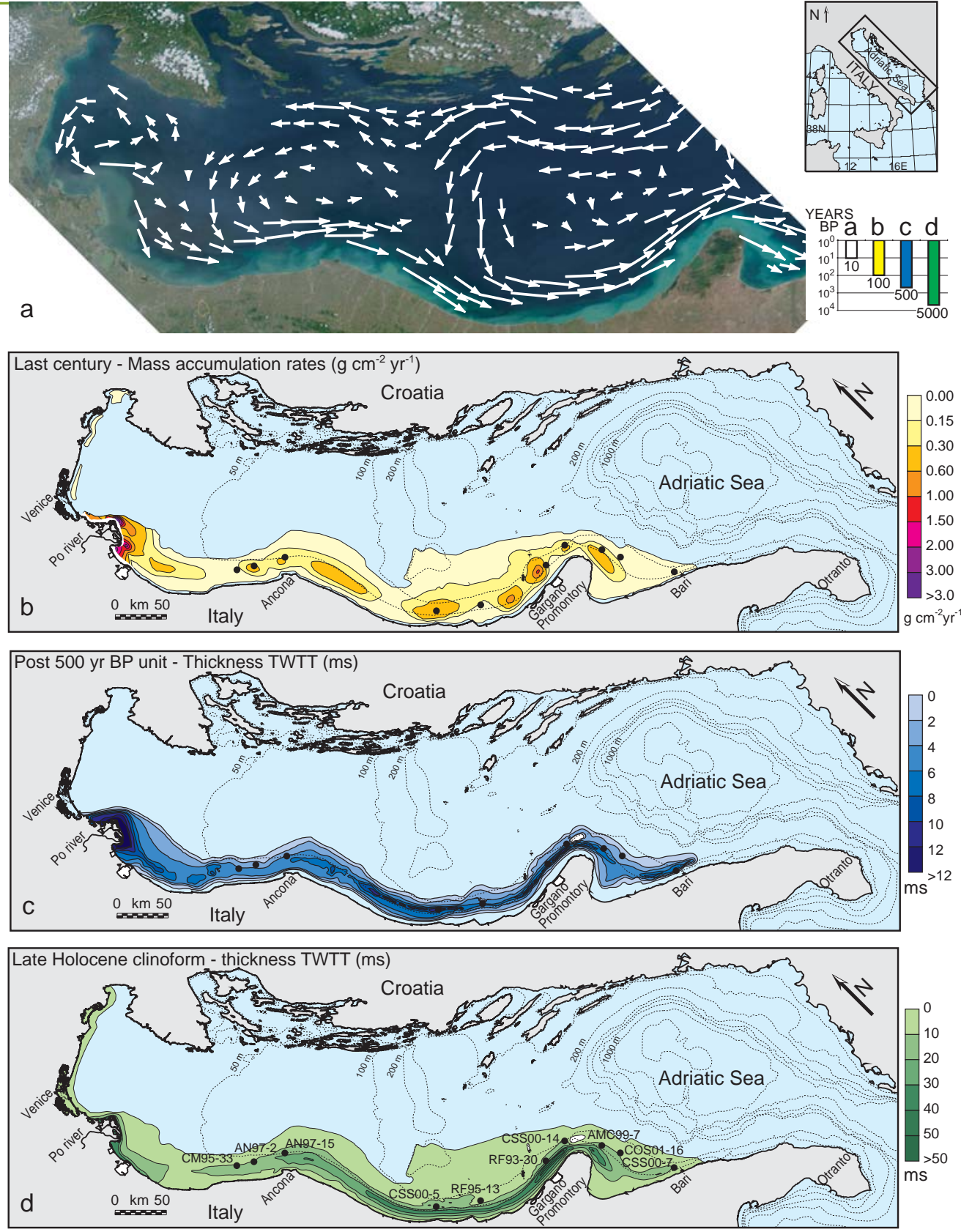

and Apennine Sediment Transport and Accumulation (PASTA) study (Puig et al., submitted). The tripods were placed on the shallow topset region and close to the clinoform rollover point at 12 $\mathrm{m}$ and $20 \mathrm{~m}$ water depths, respectively; the mooring was located at $50 \mathrm{~m}$ water depth in the foreset region. Several events of sediment re-suspension were recorded, mainly during Bora (north- easterly winds) and Scirocco (southeasterly winds) storms, when both waveorbital and current velocities increased considerably. Combined wave-current maximum shear stresses in the shallow 
topset region $(12 \mathrm{~m})$ reached values of 1 to 3 Pascals $(\mathrm{Pa})$, and appeared mainly induced by waves. At $20 \mathrm{~m}$ water depth, these values decreased by about an order of magnitude to about 0.2-0.4 Pa; in this case, shear stress induced by currents alone reached a level equal to that induced by waves. At a $50 \mathrm{~m}$ water depth, on the foreset, maximum shear stresses were just $\sim 0.1 \mathrm{~Pa}$ and were mainly induced by currents.

Sediment transport was predominantly towards the southeast, following the Western Adriatic Coastal Current (WACC), but showed a significant offshore component close to the clinoform rollover point and on the foreset region, which intensified during storm events. This offshore transport seems to be associated with an intense bottom Ekman transport, which causes the near-bottom current to be deflected to the left (in the northern hemisphere) with respect to the direction of the surface current (Figure 6). This process was not observed in the shallow topset region because the role of Coriolis force diminishes in very shallow waters, the bottom Ekman spiral cannot be formed, and the near-bottom currents become more aligned with the direction of the surface current (Csanady, 1982). Because suspended material typically occupies the lower part of the Ekman layer, the depth-integrated sediment transport occurs at an angle with respect to the depth-integrated water flow (Shapiro, 2004), favoring transport of suspended sediment from the topset to the foreset region. This across-shelf transport is particularly intense during Bora storms due to enhanced wave shear stresses causing sediment resuspension and to the strengthening of the WACC.
INTEGRATING STRATIGRAPHIC INFORMATION AND PROCESS

\section{DATA}

Foresets of the Adriatic clinoform are actively forming as documented by a progressive seaward shift in the area of active deposition through time (Figure 5). Furthermore, the overall shape of the clinoform over different time scales is elongated parallel to the western Adriatic coast, testifying to the importance of southward sediment transport. One of the major findings about clinoform generation from the EURODELTA and EUROSTRATAFORM projects is that present sediment transport is sub-parallel to the foresets, with a likely slight offshore component to allow active outbuilding basinward. Comparison of seismic stratigraphic records and sediment-accumulation rates over the last century (based on short-lived radionuclide data) shows that the largest absolute accumulation rates are encountered offshore the Po delta and just updrift of the Gargano promontory, while the offshore component of dispersal is greater in areas of flow divergence located downdrift of the coastal bulge of the Gargano promontory (Cattaneo et al., 2003) (Figure 5b).

The morphology and thickness distribution of the Adriatic shelf clinoform reflects sediment transport by the WACC parallel to the clinoform. However, the intense bottom Ekman transport observed off Pescara likely occurs along the entire western Adriatic margin associated with the extent of the WACC and contributes to cross-shelf sediment transport that allows the clinoform growth. The bottom Ekman transport would cause a veering of the near-bottom currents and a divergence of flow, causing the sediment to be moved to deeper waters where wave shear stress diminishes (Figure 6). Based on the sediment distribution "averaged" during the last ca. 5000 years, the mechanism for growth of the Adriatic clinoform due to bottom Ekman transport could have been active since the beginning of the mid-Holocene, when the Adriatic Sea acquired its modern morphology and, most probably, circulation pattern. Additional mechanisms for clinoform growth could be downwelling and seaward bottom flows (observed when winds pile water against the coast), or gravity flows triggered from river floods (not observed today, but possible before dams were constructed in Apennine Rivers).

Another important insight coming from the detailed study of the Adriatic shelf clinoform is the reason why the bottomset tapers basinward. The usual assumption for explaining this observation is that in the topset there is high, near-bed shear stress and sediment bypass is common; in the foreset, shear stress decreases and sediment accumulation is at its maximum; in the bottomset, less sediment is available and sediment accumulation decreases for this reason alone. At least in the case of the Adriatic, however, the clinoform grows basinwards and tapers out seaward, not simply because sediment is trapped in the foreset region, but because the bottom current intensifies and prevents sediment accumulation on the bottomset. These effects are visible from seismic reflection profiles (e.g., Figure 3b). Most models assume that clinoforms grow essentially as supply-limited systems; they build in equilibrium with sediment supply. The Adriatic example shows instead that the 


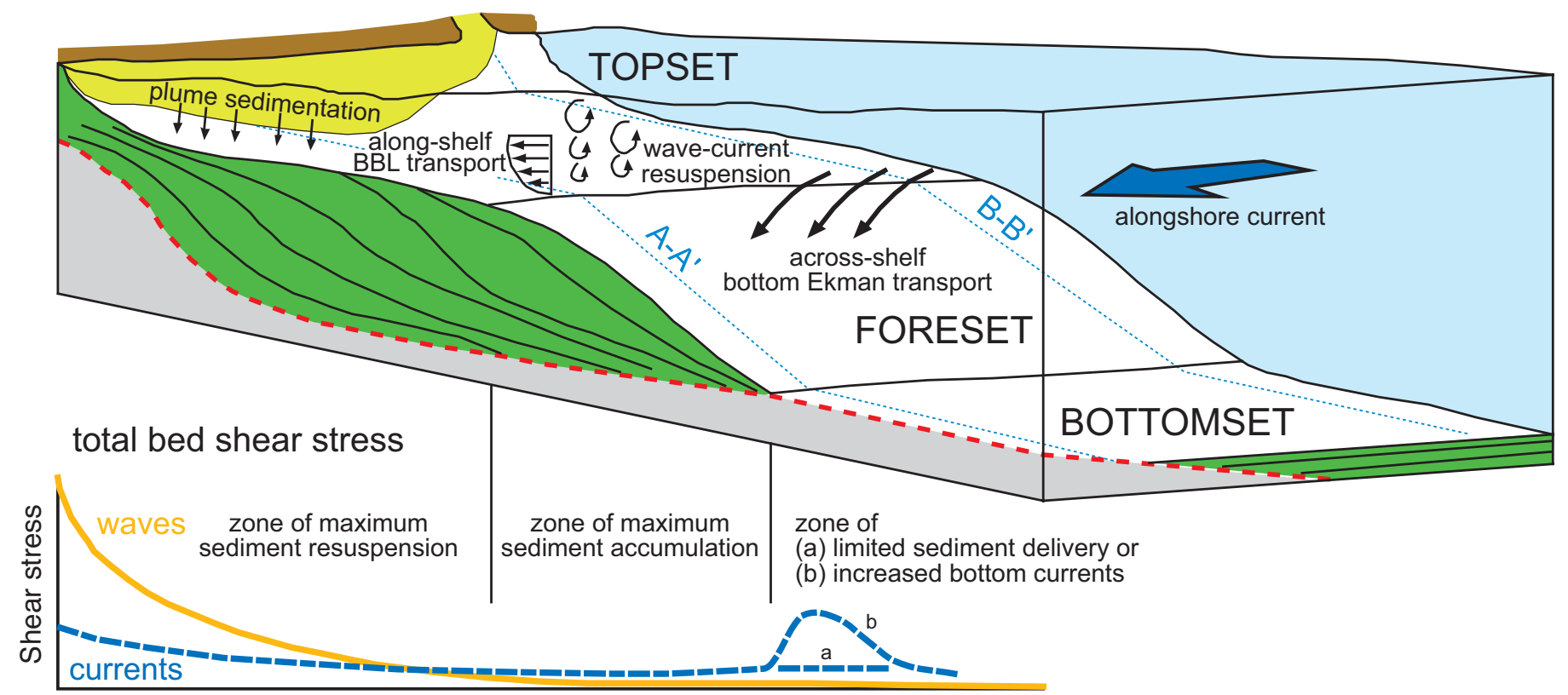

Distance

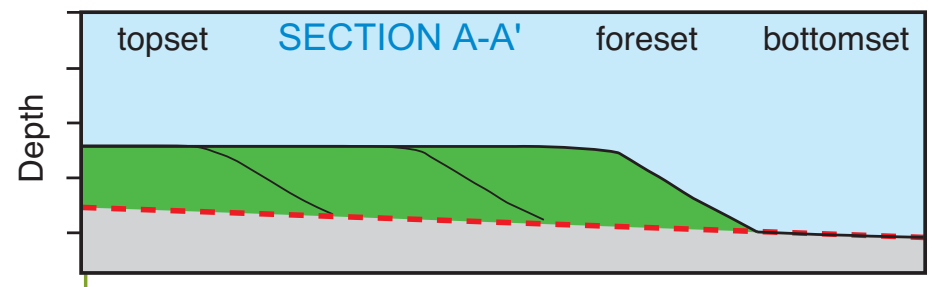

Distance

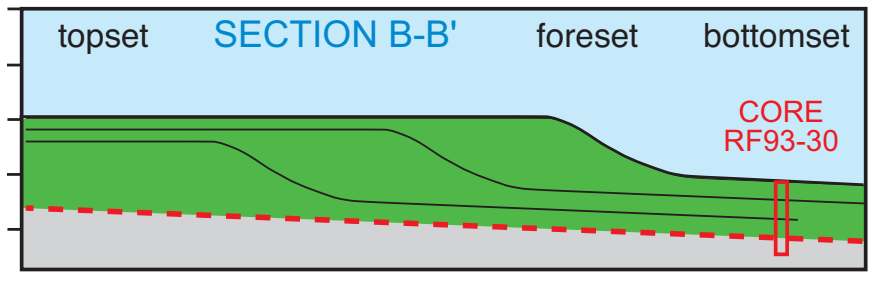

Distance

Figure 6. Three-dimensional sketch showing the main physical processes that are responsible for sediment transport across the Adriatic shelf clinoform. Two simplified stratigraphic sections show end-member arrangements of clinoform above a basal surface (dashed red line): topset and bottomset could be sites of deposition (right, the case of the central Adriatic) or not (left, the case east of Gargano). Of course, many intermediate cases are possible.

growth of a clinoform can be energy limited (as occurs off the Gargano promontory). This is the result of shore-parallel currents like the WACC, which increase energy in the bottomset region, preventing deposition.

\section{DISCUSSION AND CONCLUSION}

Simplified geological models explain the growth of clinoforms as two-dimensional features where sediment is transported exclusively across a continental margin.
Instead, clinoforms, like all geological strata packages, are three-dimensional and reflect the interplay between water depth, sediment supply, and hydrodynamics (Driscoll and Karner, 1999). In particular, the extensive research carried out on the Adriatic clinoform documents that the late Holocene clinoform grows in response to sediment advection along the margin as indicated by its shore-parallel elongation downdrift of major sediment entry points. At any site, the component of clinoform growth in a basinward direction seems to be dominated at present by bottom Ekman transport, although transport by gravity flows could have been important when Apennine Rivers were not dammed (until about 50 years ago). The physical processes that govern the clinoform growth today were likely at work over the last few thousand of years even though sediment supply was not steady and extensive river damming since the 1950 s 
induced further limitations. Secular- to decadal-scale supply fluctuations can be precisely defined based on integrated stratigraphic techniques.

Based on the Adriatic example, two main factors determine the thinning of strata in the distal clinoform: (1) the gradual decrease of sediment supply, leading to supply-limited bottomset, and/or (2) the increase of environmental energy, leading to energy-impacted bottomset. The first case, often implicitly assumed as dominant, regards the bottomset just as a distal area that passively receives less sediment. The second case, somehow overlooked, is when environmental energy increases in the bottomset because of action of bottom currents flowing along the bathymetric contour. In the Adriatic clinoform, excess energy prevents deposition in the bottomset, limiting the basinward growth of the clinoform. Furthermore, bottom currents, often oblique to the bathymetric contour, induce a lateral (rather than basinward) translation of sediment, with the formation of elongated shore-parallel clinoform bodies.

In general, it is possible to make inferences on the processes responsible for clinoform growth through the latter part of the Holocene by combining detailed observations of the anatomy of a shelf clinoform with a robust geochronologic framework and short-term sedimenttransport observations. This task unveils mechanisms of continental margins' growth; it reaches its maximum potential in the late Holocene, because, in this case, it is possible to disregard several other controlling parameters, such as sea-level changes and tectonic move- ments, which become increasingly significant over longer geological scales.

\section{ACKNOWLEDGEMENTS}

We are grateful to J. Lofi and D. Carrà for providing material for some figures. Brilliant suggestions by C.A. Nittrouer greatly enhanced this paper. We acknowledge financial support from project EURODELTA (European Co-ordination on Mediterranean and Black Sea Prodeltas; EC contract n. EVK3-CT2001-20001); EUROSTRATAFORM (EC contract n. EVK3-CT-2002-00079); and PASTA (ONR NICOP grant N00014-021-0252). This is ISMAR-Bologna (CNR) contribution n. 1429 . 四

\section{REFERENCES}

Alexander, C.R., D.J. DeMaster, and C.A. Nittrouer. 1991, Sediment accumulation in a modern epicontinental-shelf setting: The Yellow Sea. Marine Geology 98:51-72.

Cattaneo, A., A. Correggiari, L. Langone, and F. Trincardi. 2003. The late-Holocene Gargano subaqueous delta, Adriatic shelf: Sediment pathways and supply fluctuations. Marine Geology 193:61-91.

Csanady, G.T. 1982. Circulation in the Coastal Ocean, Reidel, Dordrecht, 279 pp.

Diaz, J.I., C.H. Nelson, J.H. Barber, Jr., and S. Giró. 1990. Late Pleistocene and Holocene sedimentary facies on the Ebro continental shelf. Marine Geology 95:333-352.

Driscoll, N.W., and G.D. Karner. 1999. Three-dimensional quantitative modeling of clinoform development. Marine Geology 154:383-398.

Frignani, M., L. Langone, M. Ravaioli, D. Sorgente, F. Alvisi, and S. Albertazzi. In press. Fine sediment mass balance in the western Adriatic continental shelf over a century time scale. Marine Geology.

Gensous, B. and M. Tesson. 2003. L'analyse des depôts postglaciaires et son application à l'étude des séquences de depôts du Quaternaire terminal sur la plate-forme au large du Rhône (golfe du Lion). Bulletin de la Société Géologique de France 174(4):401-419.

Goodbred, S.L., Jr., S.A. Kuehl, M.S. Steckler and M.H. Sarker. 2003. Controls on facies distribution and stratigraphic preservation in the Ganges-Brahmaputra delta sequence. Sedimentary Geology 155:301-316.

Hemleben, C., M. Spindler, and O.R. Anderson. 1989.
Modern planktic Foraminifera. Springer-Verlag, New York.

Jorissen, F.J. 1999. Benthic foraminiferal microhabitats below the sediment-water interface. In: Modern foraminifera, B.K. Sen Gupta, ed., Kluwer Academic Publisher, 61-180.

Mitchum, R.M., Jr., P.R. Vail, and J.B. Sangree. 1977. Seismic stratigraphy and global changes of sea level, part 6: Stratigraphic interpretation of seismic reflection patterns in depositional sequences. Pp. 117-133 in Seismic Stratigraphy-Applications to Hydrocarbon Exploration, C.E.Payton, ed. AAPG Memoir 26. American Association of Petroleum Geologists, Tulsa, Oklahoma.

Nittrouer, C.A., S.A. Kuehl, D.J. DeMaster, and R.O. Kowsmann. 1986. The deltaic nature of Amazon shelf sedimentation. Geological Society of America Bulletin 97:444-458.

Oldfield, F., A. Asioli, C.A. Accorsi, A.M. Mercuri, S. Juggins, L. Langone, T. Rolph, F. Trincardi, G. Wolff, Z. Gibbs, L. Vigliotti, M. Frignani, K. van der Post, and N. Branch. 2003. A high resolution late Holocene palaeoenvironmental record from the central Adriatic Sea. Quaternary Science Reviews 22:319-342.

Pirmez, C., L.F. Pratson, and M.S. Steckler. 1998. Clinoform development by advection-diffusion of suspended sediment: Modeling and comparison to natural systems. Journal of Geophysical Research 103(B10):24,141-24,157.

Poulain, P.-M. 2001. Adriatic Sea surface circulation as derived from drifter data between 1990 and 1999. Journal of Marine Systems 29:3-32.

Puig, P., A.S. Ogston, J. Guillén, A. Fain, and A. Palanques. Submitted. Sediment transport processes from the topset to the foreset of a crenulated clinoform (Adriatic Sea). Continental Shelf Research.

Rich, J.L. 1951. Three critical environments of deposition, and criteria for recognition of rocks deposited in each of them. Geological Society of America Bulletin 62:1-20.

Ruddiman, W.F. 2003. The anthropogenic greenhouse era began thousands of years ago. Climatic Change 61:261-293.

Shapiro, G.I. 2004. A 2.5D model for sand transport in a shallow sea: Effect of Ekman veering. Continental Shelf Research 24:659-671.

Stanley, D.J., and A.G. Warne. 1994. Worldwide initiation of Holocene marine deltas by deceleration of sea-level rise. Science 265:228-231.

Steckler, M.S., G.S. Mountain, K.G. Miller, and N. Christie-Blick. 1999. Reconstruction of Tertiary progradation and clinoform development on the New Jersey passive margin by 2-D backstripping. Marine Geology 154:399-420.

Van der Zwaan, G.J., and F.J. Jorissen. 1991. Biofacial patterns in river-induced shelf anoxia. Pp. 65-82 in Modern and Ancient Continental Shelf Anoxia, R.V. Tyson and T.H. Pearson, eds. Geological Society Special Publication 58. Geological Society, London. 